philosophy of judgments rests in the sound discretion and good sense of the judiciary. But then, so did the old philosophy, which was found wanting.

The good sense of this approach to the problem of finality of judgments is by no means new. Almost a century ago, Lord Campbell, setting aside a judgment long after the expiration of the term, ${ }^{36}$ said: "It is suggested that such a jurisdiction as this will be liable to abuse; but I do not feel that to be a forcible argument, as the discretion of the Court is a sufficient guarantee against abuse.... We are asked what are the limits of our jurisdiction, and whether we could do this at any time. I answer that lapse of time becomes after a season a bar, as soon as the Court in its discretion sees that it has been such as must work prejudice...." ${ }_{37}$ This philosophy is well on its way to becoming law in the federal courts.

\title{
BOND PURCHASES AT DISCOUNT BY "TNSTDER" DURING INSOLVENCY
}

Directors are denied a profit on corporate obligations purchased at a discount in three principal situations. Purchases during hopeless corporate insolvency are considered breaches of trust. Federal bankruptcy courts apply a similar rationale to acquisitions of debt which occur when reorganization proceedings are contemplated. Where the corporation is solvent at the time of acquisition, claims are limited to cost only on evidence of overreaching, either by purchasing in competition with the corporation or through misrepresentation or nondisclosure of material facts rendering the transaction inequitable to the seller.

Petitioners in the case under discussion ${ }^{\mathrm{x}}$ sought extensions of these rules and the hesitancy of the courts tested underlying theories. Calton Crescent's sole asset was an apartment building appraised on a I942 sale proposal at $\$ 220,000$, valued throughout the period for tax purposes at $\$ 421,630$, and sold in 1946 for $\$ 300,000$. Its liabilities included a $\$ 175,000$ first mortgage and $\$ 256,000$ in income debentures. By obtaining loans which enabled Calton Crescent to pay interest due on the first mortgage and tax liabilities (thus forestalling mortgage foreclosure and tax sales), two brothers gained positions on the directorate and later assumed management responsibilities. Throughout the following three years the corporation was unable to meet interest payments on its first mortgage. During that period close relatives of the Becker brothers (their mother

${ }^{36}$ Cannan v. Reynolds, 5 El. \& Bl. $30 \mathrm{I}$ (I855).

37 Cannan v. Reynolds, 5 El. \& BI. 3or, 306 ( 1855 ). The opinion of Crompton, J., at 307 , is also of interest. He states that "this case falls within the principle on which we act every day at chambers, where we set aside judgments, whether in term or out of term, on the ground of mistake. ... I do not think either that a judgment is final as soon as it is signed, and execution executed, or that it is precarious and may be set aside at any time. ... [T] application must be made within a reasonable time after the judgment is acted upon."

I Manufacturers Trust Co. v. Becker, 338 U.S. 304 (I949), aff'g. sub nom. In re Calton Crescent, Inc., I73 F. 2d 944 (C.A. 2d, I949), aff'g. 80 F. Supp. 822 (N.X., ; I948). 
and a wife), and a business associate, one Fribourg, purchased $\$ 147,300$ principal amount of the debentures for \$Io,I95 at prices ranging from 3 to I4 per cent of face value. Upon sale of the asset in 1946, Calton Crescent commenced proceedings under Chapter XI of the Bankruptcy Act ${ }^{2}$ and was able to pay 43 per cent of the principal amount of its debentures. The Becker women and Fribourg emerged as claimants of 500 per cent profit on their investment. The debenture trustee sought limitation of these claims to cost because of the relationship ${ }^{3}$ of the claimants to directors and because the purchase occurred during insolvency of the corporation.

In the lower courts the trustee made an alternative argument based on nondisclosure of material facts, an argument which it abandoned before the Supreme Court. Though the courts below found the evidence insufficient for this ground of profit denial, the Beckers admittedly were speculating on wartime real estate values and the group's purchases may have been made as clandestinely as possible, with a view to minimizing seller hesitancy which would arise if it became public that insiders were purchasing. Prospective sellers' names were supplied to a broker by Fribourg. The broker operated through Fribourg's account to buy for the Becker group, making offers of only three per cent of face value to holders. Fribourg's own purchases were made largely through an ostensible principal who made payment through a bank account opened in his name by Fribourg. 4

In federal bankruptcy proceedings, "inequity" to sellers because of misrepresentation or nondisclosure of material facts appears as one ground for limitation of claims to cost. 5 Federal application of this prophylactic rule is a recognition that lethargy, the costs of litigation, and the difficulties of proof make it unlikely that injured sellers will recover the whole of the director's profit. Directors may be tempted to take foreseen risks in the face of a rule good only in hands unwilling or unable to assert it. ${ }^{6}$ The seller's need for information is certainly pressing. When the corporation is solvent and sufficiently large to find

${ }^{2} 52$ Stat. g05 (I938), II U.S.C.A. \& 70r (1946).

3 Purchases by relatives and business associates of directors are generally treated as though made by directors. In re Van Sweringen Co., Irg F. 2d $23 \mathrm{I}$ (C.A. 6th, I94I), cert. den. 3 I4 U.S. 67I (I94I) (use of a "corporation" to purchase); In re Norcor Mfg. Co., Iog F. 2d 407 (C.A. $7^{\text {th, }}$ (940), cert. den. 3 10 U.S. 625 (1940) (corporate entity guise); In re Jersey Materials Co., 50 F. Supp. 428 (N.J., I943); Thompson v. Mitchell, I28 Wash. I92, 222 Pac. 6 I 7 (I924); Bramblet v. Commonwealth Land and Lumber Co., 26 Ky. L. Rep. II 76, 83 S.W. 599 (I904); Davis v. Rock Creek Lumber Co., 55 Cal. 359 (I880). Contra: In the matter of Franklin Bldg. Company, I78 F. 2d 805 (C.A. 7th, 1949); In re Philadelphia and Western Ry. Co., 64 F. Supp. 738 (Pa., 1946); Cumberland Corp. v. McLellan Stores Co., 32 F. Supp. 840 (N.Y., 1940); Horner v. New South Oilmill, I30 Ark. 55I, I97 S.W. II63 (I9r7).

4 Appellant's brief at 12.

5 In re Los Angeles Lumber Products Co., 46 F. Supp. 77 (Calif., I94I). See American United Mutual Life Ins. Co. v. City of Avon Park, 3II U.S. r38 (I940).

6 For recognition of this fact in another corporate context, see McCandless v. Furland, 296 U.S. I40 (I935), noted 3 Univ. Chi. L. Rev. 484 (r936); 49 Harv. L. Rev. 785 (I936). 
a place on an exchange, quotations may guide sellers. But insolvency of any sort results in nominal prices and slows trading to a point where adequate judgment even as to listed securities cannot be predicated on market information. ${ }^{7}$ SEC requirements that financial statements be accurate ${ }^{\mathbb{8}}$ are weakened by their applicability only to corporations within the federal power and by the inability of many sellers to make intelligent use of statements. Nor need these statements disclose future prospects of the corporation which would aid rival organizations.' It must seem remarkable, then, that only bankruptcy courts have given recognition to these apparent weaknesses in the seller's position. Nevertheless other courts confine application of the rule requiring candor to "insider" purchases of equity securities as distinct from secured and other indebtedness..$^{30}$ Even as to equities, grudging protection for the seller is confined to "special circumstances" and generally to face-to-face transactions. ${ }^{\text {Ix }}$ Failure to extend the candor rule to open market and over-the-counter trading weakens this slight protection further since the director can "by concealing his identity ... the more easily avoid any question relative to [the value of securities] and [can] avoid any misrepresentations on the subject." 2 That requirements discouraging trading by directors tend to deprive the corporation of profit-motivated leadership is usually given as a reason for the hesitancy of the courts to aid an injured seller. ${ }^{13}$ Arguments

7 See 59 Yale L.J. 156, n. 24 (x949); Rubin \& Feldman, Statutory Inhibitions upon Unfair Use of Corporate Information by Insiders, 95 U. of Pa. L. Rev. 468, 496 (I947).

${ }^{8}$ SEC Rule X-IOB-5 (SEC Release No. 3230, I94I), declares unlawful use of federal facilities ( $\mathrm{I}$ ) to engage in any device, scheme, or artifice to defraud, or (2) to make any untrue statement of a material fact or omission to state a material fact, or (3) perform any act, practice, or course of business which operates as a fraud or deceit upon any person in connection with the purchase or sale of any security. Infraction may be subject of injunctive relief at the suit of the Commission, criminal action, or may give rise to a private right of action by an injured party. Rubin \& Feldman, op. cit. supra note 7, at 497 .

- Compare Goodwin v. Agassiz, 283 Mass. 358, 186 N.E. 659 (r933).

${ }^{10}$ Lake, The Use for Personal Profit of Knowledge Gained While a Director, 9 Miss. L.J. 427,443 (1937).

Ix Strong v. Repide, 213 U.S. 4 Ig (Igog), announced the "special circumstances" rule. Taylor v. Wright, 69 Cal. App. $2 \mathrm{~d} 37$, I59 P. 2d 980 (r945), reviews the conflicting state authorities. Goodwin v. Agassiz, 283 Mass. 358, I86 N.E. 659 (I933), confined the rule to exclude over-the-counter purchases. But see Ballantine, Corporations 216 (1946), where it is said: "Dishonest directors should not find absolution from retributive justice by concealing their identity from their victims under the mask of the stock exchange." Where the rule of candor would apply to a director's purchases in his own behalf, it will apply to his purchases in behalf of the corporation. Wood v. MacLean Drug Co., 266 IIl. App. 5 (I932) .

I2 Strong v. Repide, 2I3 U.S. 4I9, 432 (rgog). Courts regard attempts to conceal identity as evidence of fraud. In re Van Sweringen Co., II9 F. 2d 23I, 235 (C.A. 6th, I94I). When a director attempts to derive profit through the purchases of a third person, profit is denied the third person. Cases cited note 3 supra.

13 Generally purchases made after a director abandons his position on the directorate may be enforced at full value though knowledge acquired during office is used to locate creditors and to judge the merits of speculation. Barton v. Montrose Ave. Hospital and Sanitarium, 333 Ill. App. 309, 77 N.E. 2d 423 (1948); In re Allen-Foster-Willett Co., 227 Mass. 55I, 116 
of misrepresentation or nondisclosure become even less persuasive when used as grounds for limitation of claims to cost in federal bankruptcy proceedings, since the remedy is preventive rather than compensatory. It may result in a windfall to those who retained their securities or claims but in no way aids the injured seller..$^{\mathrm{I}}$

Thus the case stood close to a possible "nondisclosure" area of profit denial. More interestingly it stood halfway between a "solvency" rationale which would have allowed profit and "insolvency" in the hopeless sense of the old cases which would have brought on automatic profit denial, for Calton Crescent was insolvent only in the equity sense of inability to meet current liabilities and in the bankruptcy sense of greater liabilities than assets.

The lower courts found that reorganization had not been contemplated ${ }^{\mathrm{s}}$ and that the corporation remained a going concern ${ }^{16}$ at the time of purchase. And if such findings are sufficient to deem the corporation solvent in the context of these rules there must have been evidence of overreaching before limitation of claims to cost. ${ }^{17}$ Overreaching occurs where claims are purchased in competition with a corporation's debt liquidation policy, whether or not the particular director was under instruction to buy for the corporation..$^{38}$ Even in absence of such a policy, profit is denied unless the director had informed a disinterested directorate of the opportunity he had discovered and unless the opportunity had been rejected by a policy against debt liquidation. ${ }^{9}$ These latter rules imply

N.E. 875 (I917); Hammond's Appeal, r23 Pa. St. 503 (1889); In re Craig's Appeal, 92 Pa. St. 396 (1880). Contra: In re McCrory Stores, I2 F. Supp. 267 (N.Y., I935), noted 34 Mich. L. Rev. I245 (r936). Profits may be realized on acquisitions made before becoming a director. Todd v. Temple Hospital Assn., Inc., 96 Cal. App. 42, 273 Pac. 595 (I929); Bonney v. Tilley, rog Cal. 346, 42 Pac. 439 (I895).

${ }^{4}$ The court of appeals found this circumstance persuasive. In re Calton Crescent, Inc.' I73 F. 2 d 944 (C.A. 2d, I949).

${ }^{25}$ I73 F. 2 d 944, 95I (C.A. 2d, I949).

${ }^{6} 80$ F. Supp. 822, 824 (N.Y., I948).

${ }^{17}$ Alexandrine Hotel v. Whaling, 313 Mich. I5, 20 N.W. 2 d 793 (I945); Punch v. Hipolite Co., 340 Mo. 53, I00 S.W. 2d 878 (1936); Claude Neon Lights, Inc. v. Federal Electric Co. 295 N.X. Supp. I, 250 App. Div. 5Io (I937); Camden Safe Deposit Co. v. Citizen's Ice Co., 69 N.J. Eq. 718, 6I Atl. 529 (1905); McIntyre v. Ajax Mining Co., 28 Utah 162, 77 Pac. $6 \mathrm{r}_{3}$ (rg04); Glenwood Mfg. Co. v. Syme, Iog Wis. 355, 85 N.W. 432 (Igor); Seymour v. Spring Forest Cemetery Assn., I44 N.Y. 333, 39 N.E. 365 (I895).

${ }^{18}$ Particular director designated the corporation's agent to buy: Atherton v. Emerson, r99 Mass. I99, 85 N.E. $53^{\circ}$ (rgo8); Kroegher v. Calivada Colonization Co., II9 Fed. $64 \mathrm{I}$ (C.A. 3d, I902); Kimmell v. Geeting, 2 Grant I25 (Pa., I853). Corporation merely had a liquidation policy: Davis v. Rock Creek Lumber Co., 55 Cal. 359 (I88o); cf. Glenwood Mfg. Co. v. Syme, rog Wis. 355,85 N.W. 432 (rgor).

19 The decisions require that the director notify the company of the opportunity before purchasing himself. Glen Allen Mining Co. v. Park Galena Mining Co., 77 Utah 362, 296 Pac. 23 I (I93) ; In re Jersey Materials Co., 50 F. Supp. 428 (N.J., I943); The Telegraph v. Lee, I25 Iowa $x_{7,93}$ N.W. $36_{4}$ (Ig04). Where a director's disclosure is dishonest, profit is denied. Wabunga Land Co.v. Schwanbeck, 245 Mich. 505, 222 N.W. 707 (I929). The directorate must be disinterested. Ripperger v. Allyn, 25 F. Supp. 554 (N.Y., 1938); Young v. Columbia Land and Investment Co., 53 Ore. 438, 99 Pac. 936 (Igog). 
that the company had cash or credit sufficient to purchase the outstanding obligations. Calton Crescent had none and presumably emptiness of treasury justifies a director's actions in his own behalf..$^{20}$

Yet the court might have held "equity" or "bankruptcy" insolvency the equivalent of "hopeless insolvency" for the purpose of denying profit. One may wonder how realistic it is to say that Calton Crescent was a "going concern" and that reorganization had not been contemplated at the time of the purchases. Corporate demise, either through tax or foreclosure sales, was prevented only by the financial propping of the Becker group, and it is doubtful that that group ever expected to pay creditors in full.

The rule denying profit where the corporation was "hopelessly insolvent" is similar to the misrepresentation or nondisclosure rule discussed above in the prophylactic nature of its application. ${ }^{2 x}$ It applies regardless of perfect candor in dealing with the seller, ${ }^{22}$ of the director's motives in purchasing, ${ }^{23}$ or of bene-

${ }^{20}$ Alexandrine Hatel v. Whaling, 313 Mich. I5, 20 N.W. 2 d 793 (I945); Punch v. Hipolite Co., 340 Mo. 53, roo S.W. 2 d 878 (1936); Glenwood Mfg. Co. v. Syme, Io9 Wis. 355, 85 N.W. 432 (rgor). But cf. Irving Trust Co. v. Deutsch, 73 F. 2 d I2I (C.A. 2d, I934), cert. den. 294 U.S. 709 (I934), refusing the defense in an opportunity seizure situation. It was feared that if directors were given a "no funds" justification for entering into competition with the corporation their efforts to raise rew capital would decrease. Application of the Deutsch doctrine in the obligations-purchase situation has been suggested. In re Los Angeles Iumber Products Co., 46 F. Supp. 77 (Calif., I94I); Punch v. Hipolite Co., 340 Mo. 43, 72, I00 S.W. 2d 878, 888 (I936). It is at least conjectural whether the danger that directors will provide themselves a defense by failing to exert best efforts to find new funds is as great in the situation where new money is to be used to buy old debts as where it is to be used to expand healthy enterprise. It is thought that the latter situation invites new capital whereas the former repels it. The danger is at least lessened by the hopelessness of the director's situation. Prospective lender's reluctance to part with new money is to be expected where old money has experienced losses reflected by the discount.

${ }^{2 x}$ All courts have denied profit in such a case. Thompson v. Mitchell, I28 Wash. 192, 222 Pac. 6I7 (1924); Bramblet v. Commonwealth Land and Lumber Co., $26 \mathrm{Ky}$. L. Rep. II76, 83 S.W. 599 (I904); Bonney v. Tilley, rog Cal. 346, 42 Pac. 439 (I895). Knowledge of impending insolvency is presumed from position as officer or director. Atherton v. Emerson, I 99 Mass. 199, 85 N.E. $53^{\circ}$ (1908). If the director has transferred a claim purchased at a discount to a purchaser without notice, presumably the third party may enforce in full. See Inglehart $\mathrm{v}$. Thousand Island Hotel Co., 32 Hun. 377 (N.Y., 1884). But a court may enjoin such transfers. In re Los Angeles Lumber Products Co., 46 F. Supp. 77 (Calif., r94I). Where a director retained part and sold part of his discount purchases, his recovery on the claims retained was cut to cost, and from cost was subtracted the profit made in the sale to a third party. In re Philadelphia and Western Ry. Co., ${ }_{4}$ F. Supp. 738 (Pa., I946). Where a third party purchases for himself and the director as "joint adventurers," the third party participates in a breach of trust and thus cannot recover. See cases cited note 3 supra.

22 Claims have been denied a profit even where the purchasing director urged sellers against selling. In re Los Angeles Lumber Products Co., 46 F. Supp. 77 (Calif., I94I). Compare In re Franklin Bldg. Co., I78 F. 2d 805 (C.A. 7th, I949) (bondholder's committeeman); L. Hand, J., in In re National Public Service Corp., 68 F. 2d 859, 869 (C.A. 2d, I934): "It is not enough that a creditor has means of information; he may insist that his interests shall $b e$ in the hands of a trustee who can act without embarrassing cross currents of motive; that he [the creditor] shall not be required to prove that the trustee has failed to press his interests; that the trustee's impartiality must be free from all question," quoted with approval in the Los Angeles Lumber Products case.

${ }^{23}$ Compare In the matter of Franklin Bldg. Co., I78 F. 2d 805 (C.A. 7th, I949). 
fits to the corporation arising from his purchase. ${ }^{24}$ The rule apparently had its origin in the inclination of early courts to announce a desired result by stating that the assets of an insolvent corporation were held in trust for the benefit of creditors. ${ }^{25}$ Having thus spoken, it followed that directors were trustees and could not deal in the obligations of the corporations lest their interests be divided.

Yet the trust analogy is not utilized to deny profit in analogous situations. A director may make loans to his corporation, ${ }^{26}$ if entered fairly and interest rates are reasonable, regardless of the corporation's financial condition..$^{27}$ This is so despite possible conflict of interest where the corporation would best be served by gaining an extension after maturity date, or where the director's desire for profit might lead him to keep the loan active in order to prolong interest periods. Little different is the case where the director purchases an obligation at full value. ${ }^{28}$ The possibilities of loyalty division here are no greater than those presented where the director is a party to the original transaction. Any of these transactions may place preferred claims in the hands of a director. These are subordinated only when the director seeks to pay himself in preference to others. ${ }^{29}$

"It is not immediately apparent why insolvency should make a difference." $3^{\circ}$ However, dangers of loyalty division significantly increase upon insolvency. As recited above, insolvency increases the disparity of knowledge between insiders and sellers. It also increases the discount, hence possibilities of profit. The fact that the director is quite often a representative of junior claims renders it advantageous for him to move from an equity to a creditor's position on the corporate ledger..$^{3 x}$ Yet any speculator is likely to be directed by the same profit

${ }_{24}^{4}$ In re McCrory Stores, I2 F. Supp. 267 (N.Y., I935).

${ }_{25}$ In re Philadelphia and Western Ry. Co., 64 F. Supp. 738 (Pa., 1946); 3 Fletcher, Cyclopedia Corporations $\$ 869$ ( 1947 ); Ballantine, Corporations 209 (1946). Fiduciary language may be considered window dressing in the many cases in which profit might have been denied on an "overreaching" theory.

${ }^{26}$ Sanford Tool Co. v. Howe, Brown \& Co., I57 U.S. $3^{\text {I2 }}$ (I894); Twin-Lick Oil Co. v. Marbury, 9 I U.S. 587 (I875); Monroe v. Scofield, $x_{35}$ F. 2 d 725 (C.A. Ioth, I943); Camden Safe Deposit and Trust Co. v. Citizen's Ice Co., 69 N.J. Eq. 718, 6r Atl. 529 (rg05).

${ }_{27}$ Higgins v. Lansingh, I54 Ill. 301,40 N.E. 362 (1895).

${ }^{28}$ Marine and River Phosphate Mining Co. v. Bradley, ro5 U.S. 175 (I88I); Stack v. Welder, I37 Cal. App. 647, 3x P. $2 \mathrm{~d} 426$ (I934); Snediker v. Ayers, $\mathrm{x}_{4} 6$ Cal. 407 , 80 Pac. 5 II (rgo5).

29 Claims retained their preference: Martin v. Chambers, 214 Fed. 769 (C.A. 5 th, $19 \mathrm{I} 4$ ); Stack v. Welder, I37 Cal. App. 647, ${ }_{1}$ P. 2 2d 426 (I934); cases cited note 28 supra. Claims subordinated because of attempted self-payment: Atherton v. Emerson, I99 Mass. 199, 85 N.E. 530 (Ig08); Asheville Lumber Co. v. Hyde, 172 Fed. 73 (C.C. Pa., 1909). Compare Pepper v. Litton, 308 U.S. 295 (1939).

30 In re Calton Crescent, I73 F. 2d 944, 950 (C.A. 2d, 1949).

${ }^{3 x}$ Note the following testimony of a president-director: "I and the other directors felt that to protect my own interest I ought to get control of the [corporation] and its property. I was looking out for myself. ..." Glen Allen Mining Co. v. Park Galena Mining Co., 77 Utah 362 , 376, 296 Pac. 231, 237 (933). 
and control motives. It is true that the "inside" position and power of the director give him certain advantages over "outsiders." He knows who are the claim holders and his knowledge of the value of remaining assets is likely to be superior to that of the seller and of the "outside" speculator. Yet one must ask whether the mere fact that a director has these advantages over "outsiders" in the obligations-purchase race is sufficient reason for the automatic denial inherent in the "trust" rationale. Given some device, perhaps administrative, ${ }^{32}$ strengthening the seller's knowledge, parity recognition of a purcbasing director's claims on corporate reorganization would tend to keep the enterprise in experienced hands.

That the director's purpose in purchasing obligations may be to prop up the corporate structure in order to safeguard his own previously-acquired junior interests is another factor urging rejection of the "trust" rationale. ${ }^{33}$ As long as an invitation to participate is extended to all interested parties there seems no reason why those who refuse should be allowed windfall gains. Nevertheless, profit is denied though other equity holders have abandoned the corporation to the creditors. ${ }^{34}$ And oftentimes a director's activity is of substantial benefit to the corporation, despite his own speculative purposes. ${ }^{35}$ Thus, in the principal case, the Becker activity matured in a manner profitable to all those who retained debentures. Had the corporation accepted the I942 proposal to sell for $\$ 222,000$, the distribution to the bondholders would have been five percent of face value..$^{36}$ By delaying foreclosure, the group made possible a sale for $\$ 300, \infty 00$, a distribution of 43 percent and a profit to themselves of $\$ 54,000$. If the claims of the Becker group had been denied, nonselling bondholders would have received a windfall of 50 per cent or a distribution of 94 percent. And it is a fair guess that many of the "retaining" bondholders were recent acquirers, as were the Beckers, at the average market price during the period of 8 per cent. In the usual, though not in the principal case, the efforts of a director seeking to

${ }^{32}$ See 62 Harv. I. Rev. I39I, ${ }_{392}$ (I949), noting the principal case.

${ }^{33}$ Aside from ( $\mathrm{x}$ ) profit and control, or (2) safeguarding junior interests, the old cases reveal a third motive of directors in purchasing claims at a discount. Directors sought to use these claims as set-off cushions against various statutory liabilities. In Bulkley v. Whitcomb, I2I N.Y. ro7, 24 N.E. I3 (1890), and Lingle v. Nat. Ins. Co., 45 Mo. Iog (I869), set-offs were attempted, but refused, against liability on unpaid stock subscriptions. In Hill v. Frazier, 22 Pa. St. 320 ( 1853 ), the director's liability for issuance of stock in impairment of capital could not thus be avoided. Assessment litigation on unpaid stock subscriptions brought by directors against the shareholders was successful in In re Craig's Appeal, 92 Pa. St. 396 (I880), since the directors had purchased after the corporation had ceased business. But cf. Chouteau Insurance Co. v. Floyd, 74 Mo. 286 (r88I).

34 Monroe v. Scofield, I35 F. 2d 725 (C.A. Ioth, I943); Bramblet v. Commonwealth Land and Lumber Co., 26 Ky. L. Rep. Ix 76, 83 S.W. 599 (I904); Harts v. Brown, 77 Ill. 226 (I875).

35 Monroe v. Scofield, r35 F. $2 d 725$ (C.A. roth, 1943); In re McCrory Stores, I2 F. Supp. 267 (N.Y., I935); Bramblet v. Commonwealth Land and Lumber Co., 26 Ky. L. Rep. Ix76, 83 S.W. 599 (1904). Compare Punch v. Hipolite Co., 340 Mo. 53, I00 S.W. 2d 878 (1936); Hauben v. Morris, 255 App. Div. 35, 5 N.Y.S. $2 d$ 721 (I938).

${ }^{36}$ The figure five per cent is drawn from the opinion of the court of appeals, I73 F. 2d 944, 947 (C.A. 2d, 1949). 
salvage equity interests will deserve more sympathy from a court of equity than the efforts of an outside speculator to capture derelict assets.

In addition, bankruptcy rules for determining fairness of reorganization plans tend to minimize the danger that a director will seek to retain control through discount purchases. "Where ... [the investigation of a bankruptcy court] discloses the existence of unfair dealing, a breach of fiduciary obligations, profiting from a trust, special benefits for the reorganizers, or the need for protection of investors against an inside few, or of one class of investors from the encroachments of another, the court has ample power to adjust the remedy to meet the need. The requirement of full, unequivocal disclosure; . . the separate classification of claimants; the complete subordination of some claims, indicate the range and type of the power which a court of bankruptcy may exercise in these proceedings. That power is ample for the exigencies of varying situations: It is not dependent on express statutory provisions. It inheres in the jurisdiction of a court of bankruptcy." 37 Thus on general equitable principles a bankruptcy court may disregard or limit the voting power of cheaply acquired corporate obligations which have a veto power over interests of longer standing, when the purpose of the holders is either to extort profit or control for their acceptance of a plan from others, or to vote in an inequitable plan. ${ }^{38}$ The Bankruptcy Act itself requires judicial scrutiny of claims asserted by agents, attorneys, committees, indenture trustees and a limiting of such claims as were acquired in contemplation of or in the course of reorganization proceedings to the actual consideration paid. ${ }^{39}$ Analogous safeguards are provided against trading by members of bondholders committees, whose positions are more nearly similar to those of trustees than is that of a director..$^{\circ}$

It was in the background of these conflicting considerations, the myriad federal statutes which have sought since I929 to protect investors from insider trading, and the general powers of bankruptcy courts to discourage such transactions that the Supreme Court was asked to decide the Calton Crescent situation. The Court emphasized that the issue was whether the facts of the particular case gave rise to possibilities of division of loyalty so apparent as to compel application of the "trustee" rule of the early courts in the "hopeless" insolvency cases where the corporation was insolvent only in a bankruptcy sense..$^{4 x}$ In

37 American United Mutual Life Ins. Co. v. City of Avon Park, 3 II U.S. I38, I46 (I940).

${ }^{38}$ In re McEwen's Laundry, Inc., 90 F. 2d 872 (C.A. 6th, 1937).

39 Bankruptcy Act $\S 212,52$ Stat. 895 ( $x_{93} 8$ ), II U.S.C.A. $\$ 6$ I2 (I946).

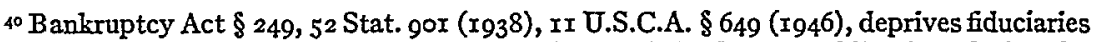
in corporate reorganizations of compensation if they trade in shares or obligations during the period of office. In re Mountain States Power Co., 35 F. Supp. 307 (Del., I940); In re Republic Gas Corp., 35 F. Supp. 300 (N.Y., I936).

${ }^{4 \pi}$ The precise issue has not been squarely raised in previous cases. In re Van Sweringen Co., II9 F. 2d 23 I (C.A. 6th, I94I), cert. den. 3 I $_{4}$ U.S. 67 I (r94I), perhaps most strongly supported the trustee, since the fact that the purchases there occurred one year before bankruptcy proceedings was so distant from the court's view of what was material that it was not men- 
behalf of such an extension, the SEC urged that directors might be tempted to delay the reorganization or liquidation of a losing concern to gain time in which to purchase obligations and that delays might waste assets rightfully belonging to all creditors. Judge Learned Hand's dissent in the court of appeals argued that "[ $t$ ]he insolvent company may have a good chance of effecting a composition: that is, it may be able to scale down its debts and go on," 42 and that courts should ask, in each case, whether the alternatives to "scale down and go on" or to buy at discount and realize a profit are sufficiently present to require the trustee rule against divided loyalty. ${ }^{43}$ In refusing to extend the trust rule, the Court adopted Judge Hand's approach to the problem since it limited its decision to the particular facts and suggested another result in Chapter $\mathrm{X}$ proceedings should the SEC, as "statutory advisor to the court" present a convincing "body of evidence ... presumably informed by expert understanding."

The Court's refusal recognizes that the trust rule is based on speculation as to causes and effects of conflicting considerations and that earlier courts may have been too deaf to argument in behalf of the director. Looked upon as a realization that recent federal regulations and bankruptcy cases have lessened the dangers of divided loyalty, perhaps the decision portends further restrictions on the application of the trust rule as protections against "insider" transactions are strengthened. Analogous safeguards on the state level leading to similar limitations of the rule will prove of greater significance, however, since the discount purchase problem is peculiar to small corporations controlled by state regulation and jurisprudence.

\section{YOUTH CORRECTION-THE MODEL ACT IN OPERATION}

$\mathrm{I}$

Though vengeance was, historically, the motive for criminal punishment, ${ }^{3}$ modern justifications are based on the prevention of future crimes. ${ }^{2}$ Punishment,

tioned in the opinion, but was recited in Gochenour v. Cleveland Buildings Co., $\mathrm{x}_{4} 2 \mathrm{~F}$. $2 \mathrm{~d}$ 99I, 992 (C.A. 6th, I944). In re Jersey Materials Co., 50 F. Supp. 428 (N.J., I943), was a case of competition with the corporation in making the purchases and thus stood on grounds alternative to the trust rationale. In In re Los Angeles Lumber Products Co., 46 F. Supp. 77 (Calif., I94I), the claims were purchased after a resolution approving reorganization proceedings and in In re Norcor Mfg. Co., Iog F. 2 d 407 (C.A. 7th, I940), cert. den. 3 Io U.S. 625 (r940), the corporation was in state receivership at the time of purchase.

4273 F. 2d 944, 952 (C.A. 2d, I949).

${ }^{43}$ A similar attitude is revealed by the Chenery cases, 3 I8 U.S. 80 (r943), which held that equity (i.e., common law) had not imposed upon officers and directors any fiduciary duty to shareholders precluding them from buying and selling corporate stock even during reorganization proceedings. But the Court, in 332 U.S. I94 (r947), conceded the SEC's ability to impose such a rule in the light of its experience.

$\therefore$ Waite, The Prevention of Repeated Crime 3-89 (I943); Waite, The Youth Correction Authority Act, 9 Law \& Contemp. Prob. 600, 600-602 (I942).

2 Ibid. This is not to say that the punitive element is not present in modern theories, for in all probability, the desire for retribution is consciously or unconsciously always a motiva- 